\title{
Protective effect of Acacia confusa bark extract and its active compound gallic acid against carbon tetrachloride-induced chronic liver injury in rats
}

\author{
Yu-Tang Tung ${ }^{\text {, }}$ Jyh-Horng Wu ${ }^{\mathrm{b}}$, Chi-Chang Huang ${ }^{\mathrm{c}}$, Hsiang-Chi Peng ${ }^{\mathrm{d}}$, Ya-Ling Chen ${ }^{\mathrm{d}}$, \\ Suh-Ching Yang ${ }^{\mathrm{d}, *}$, Shang-Tzen Chang ${ }^{\mathrm{a}, *}$ \\ a School of Forestry and Resource Conservation, National Taiwan University, Taipei 106, Taiwan \\ ${ }^{\mathrm{b}}$ Department of Forestry, National Chung-Hsing University, Taichung 402, Taiwan

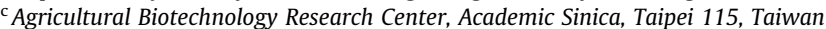 \\ ${ }^{\mathrm{d}}$ Nutrition and Health Sciences, College of Public Health $\mathcal{E}$ Nutrition, Taipei Medical University, Taipei 110, Taiwan
}

\section{A R T I C L E I N F O}

Article history:

Received 17 September 2008

Accepted 17 March 2009

\section{Keywords:}

Acacia confusa

Gallic acid

Carbon tetrachloride

Hepatoprotective effect

CYP2E1

\begin{abstract}
A B S T R A C T
Acacia confusa Merr. (Leguminosae), a species native to Taiwan, is widely distributed on the hills and lowlands of Taiwan, and has been traditionally used as a medicine. The hepatoprotective effects of $A$. confusa bark extract $(A C B E)$ and its active constituent gallic acid were evaluated against carbon tetrachloride $\left(\mathrm{CCl}_{4}\right)$-induced hepatotoxicity in rats. $\mathrm{CCl}_{4}$-induced hepatic pathological damage and significantly increased the levels of aspartate aminotransferase (AST), alanine aminotransferase (ALT) and malondialdehyde (MDA) in plasma, and cytochrome P4502E1 (CYP2E1) protein expression in hepatic samples, and decreased the activities of superoxide dismutase (SOD), glutathione peroxidase (GPX) and catalase (CAT) in erythrocytes. Treatment with ACBE, gallic acid or silymarin could decrease significantly the AST, ALT, and MDA levels in plasma, and CYP2E1 expression in liver tissues, and increase the activities of SOD and GPX in erythrocyte when compared with $\mathrm{CCl}_{4}$-treated group. Liver histopathology also showed that $\mathrm{ACBE}$, gallic acid or silymarin could significantly reduce the incidence of liver lesions induced by $\mathrm{CCl}_{4}$. $\mathrm{These}$ results suggested that the $\mathrm{ACBE}$ and gallic acid exhibit potent hepatoprotection against $\mathrm{CCl}_{4}$-induced liver damages in rats, and the hepatoprotective effects of ACBE and gallic acid may be due to the modulation of antioxidant enzymes activities and inhibition of lipid peroxidation and CYP2E1 activation.
\end{abstract}

Crown Copyright (c) 2009 Published by Elsevier Ltd. All rights reserved.

\section{Introduction}

According to the statistics tabulated by the Department of Health, Taiwan in 2007, chronic liver disease and cirrhosis constitute 7th leading cause of death in Taiwan. Unfortunately, there are certain limitations in the treatment of hepatitis. A number of researchers pointed out that in addition to hepatic problems, carbon tetrachloride $\left(\mathrm{CCl}_{4}\right)$ also causes acute and chronic hepatic damage due to free radical generations (Liao et al., 2007; Jain et al., 2008; Hung et al., 2006; Wills and Asha, 2006). $\mathrm{CCl}_{4}$ is metabolized by cytochrome P4502E1 (CYP2E1) to become trichloromethyl radical $\left(\mathrm{CCl}_{3}\right)$ and proxy trichloromethyl radical $\left(\cdot \mathrm{OOCCl}_{3}\right)$, which are assumed to initiate free radical-mediated lipid peroxidation leading to the accumulation of lipid-derived oxidation products that cause liver injury (Liao et al., 2007; Poli et al., 1987; Recknagel et al., 1989; Shyur et al., 2008). Silymarin, a mixture of flavonolignanes from milk thistle (Silybum marianum L.), is a hepatoprotective herbal medicine worth $\$ 180$ million dollars of

\footnotetext{
* Corresponding authors. Tel.: +886 2 33664626; fax: +886 223654520.

E-mail addresses: sokei@tmu.edu.tw (S.-C. Yang), peter@ntu.edu.tw (S.-T. Chang).
}

business annually in Germany alone. Silymarin could effectively prevent $\mathrm{CCl}_{4}$-induced liver injury, indicating that oxidative stress is responsible for $\mathrm{CCl}_{4}$-induced hepatic disorder (Liao et al., 2007). A number of studies showed that various herbal extracts could protect liver against $\mathrm{CCl}_{4}$-induced oxidative stress by altering the levels of increased lipid peroxidation, and enhancing the decreased activities of antioxidant enzymes such as superoxide dismutase (SOD), catalase (CAT) and glutathione-S-transferase (GST) as well as the decreased level of the hepatic-reduced glutathione (GSH) (Lu and Liu, 1992; Jain et al., 2008; Hsiao et al., 2003; Hung et al., 2006; Wills and Asha, 2006).

Acacia confusa Merr. (Leguminosae), a native species to Taiwan, is widely distributed on the hills and lowlands of Taiwan, and has been traditionally used as a medicine (Wu et al., 2005). An aqueous extract of $A$. confusa leaves was used in Taiwan for wound healing and anti-blood-stasis (Kan, 1978). The crude extracts of $A$. confusa bark contain a wide variety of phenolic compounds (Chang et al., 2001; Tung et al., 2007, 2009). Recent studies have shown that some phenolic compounds can prevent $\mathrm{CCl}_{4}$-induced hepatic damage, and the ability of phenolic compounds might be related to their antioxidant properties (Hung et al., 2006; Jadon et al., 2007). Thus, the objective of this study was performed to evaluate 
the potential protective effects of ethanolic crude extract and its active compound, gallic acid, from $A$. confusa bark in $\mathrm{CCl}_{4}$-induced chronic liver injury in Sprague Dawley rats.

\section{Materials and methods}

\subsection{Preparation of $A$. confusa bark extract $(A C B E)$}

The bark of A. confusa was sampled from the experimental forest of National Taiwan University in Nan-Tou County. The species was identified by Sheng-You Lu of the Taiwan Forestry Research Institute, and a voucher specimen (AC001) was deposited at the School of Forestry and Resource Conservation, National Taiwan University. The materials were air dried at room temperature $\left(25^{\circ} \mathrm{C}\right)$. The dried samples were cut into small pieces and soaked in $70 \%$ ethanol at room temperature for 7 days. The extract was filtered through Whatman No. 2 filter paper, and the filtrate was concentrated in a rotary evaporator and then lyophilized. Gallic acid (3,4,5-trihydroxybenzoic acid) content in crude extracts isolated and identified from the EtOAc fraction of $A$. confusa bark ranged from 31.6 to $34.7 \mu \mathrm{g}$ per gram of crude extract.

\subsection{Treatment of animals}

A total of 42 male Sprague Dawley rats (body weight 220-230 g) were obtained from the Laboratory Animal Center of National Taiwan University of College and Medicine. The rats were housed in individual cages with free access to water and standard powdered diet (Lab5001 powder from USA PMI) at a temperatureand humidity-regulated environment $\left(22 \pm 2{ }^{\circ} \mathrm{C}, 65 \pm 5 \% \mathrm{RH}\right)$ with $12 \mathrm{~h}$ dark/light cycle. Experiments were started after the animals were allowed to adapt to the individual stainless-steel cages for one week. Regarding to the dosage used in the experiment, it is well-known that protocatechuic acid (3,4-dihydroxyl benzoic acid), the analog of gallic acid, exhibited an excellent protection activity against $\mathrm{CCl}_{4}$-induced hepatic damage in rats at a dose of $100 \mathrm{mg} / \mathrm{kg}$ of bw (Hung et al., 2006). However, gallic acid has better antioxidant activity than protocatechuic acid by various in vitro assays (Tung et al., 2007, 2009). Thus, in this study, the major bioactive phytocompound of ethanolic extract from A. confusa bark, i.e. gallic acid, was tested at a relatively low dose of $50 \mathrm{mg} / \mathrm{kg}$ of bw. For the examination of both aspartate aminotransferase (AST) and alanine aminotransferase (ALT) activities in the plasma, 42 rats were randomly assigned to seven groups $(n=6)$ ): olive oil (control group), $\mathrm{CCl}_{4}$ injection ( $\mathrm{CCl}_{4}$ group), dietary supplementation with silymarin at a dose of $50 \mathrm{mg} / \mathrm{kg}$ plus $\mathrm{CCl}_{4}$ injection (silymarin $+\mathrm{CCl}_{4}$ group), dietary supplementation with $\mathrm{ACBE}$ at a relatively low dose of $50 \mathrm{mg} / \mathrm{kg}$ plus $\mathrm{CCl}_{4}$ injection (L-AC$\mathrm{BE}+\mathrm{CCl}_{4}$ group), dietary supplementation with $\mathrm{ACBE}$ at a relatively high dose of $250 \mathrm{mg} / \mathrm{kg}$ plus $\mathrm{CCl}_{4}$ injection ( $\mathrm{H}-\mathrm{ACBE}+\mathrm{CCl}_{4}$ group), dietary supplementation with ACBE at a relatively high dose of $250 \mathrm{mg} / \mathrm{kg}$ (H-ACBE group), dietary supplementation with gallic acid at a dose of $50 \mathrm{mg} / \mathrm{kg}$ plus $\mathrm{CCl}_{4}$ injection ( $\mathrm{GA}+\mathrm{CCl}_{4}$ group). Rats were fed powdered diet admixed with silymarin, ACBE or gallic acid combination for two weeks prior to $\mathrm{CCl}_{4}$ injection and throughout the experiment. Silymarin has been used in the treatment and prevention of liver disease in clinic (Chang et al., 2009; Kuriakose and Kurup, 2008; Gowri Shankar et al., 2008). Thus, in this study, it was used as a positive control. During the 8-week experimental period, the amounts of silymarin, ACBE and gallic acid were administered according to weekly body weight. $\mathrm{CCl}_{4}$-induced hepatotoxic rats were subcutaneously injected with $0.75 \mathrm{~mL} / \mathrm{kg}$ bw of $40 \% \mathrm{CCl}_{4}$ dissolved in olive oil once a week, while rats in control group were injected with olive oil only.

Blood samples were collected from the tail vein into heparin-containing tubes and plasma samples were obtained by centrifuging at $1200 \mathrm{~g}$ for $15 \mathrm{~min}$. After removing plasma, erythrocytes were obtained by washing two times with ice-cold physiological saline. At the end of the experiment, each rat was to be anesthetized by ethyl ether, the liver was immediately perfused with ice-cold normal saline, then carefully removed, rinsed in ice-cold normal saline, blotted dry and weighed. All samples were stored at $-80^{\circ} \mathrm{C}$ for assay.

\subsection{Pathological histology}

Liver tissue was fixed in 10\% buffered formaldehyde and processed for histological examination according to three kinds of histopathological stain including hematoxylin and eosin (H\&E), Masson, and silver stains.

\subsection{Western blot analysis of hepatic microsomal CYP2E1 protein}

Western blot analysis of hepatic microsomal CYP2E1 protein was measured according to the method of Huang et al. (2005). Liver tissues were homogenized in 10 volumes of ice-cold buffer $(0.25 \mathrm{~mol} / \mathrm{L}$ sucrose, $10 \mathrm{mmol} / \mathrm{L}$ Tris- $\mathrm{HCl}$, and $0.25 \mathrm{mmol} / \mathrm{L}$ phenylmethylsulfonyl fluoride, $\mathrm{pH}$ 7.4). The homogenates were centrifuged at $17,000 \mathrm{~g}$ for $20 \mathrm{~min}$ at $4{ }^{\circ} \mathrm{C}$. Then the supernatant was centrifuged at $105,000 \mathrm{~g}$ for $60 \mathrm{~min}$ at $4{ }^{\circ} \mathrm{C}$ to separate the microsomes. The microsomal pellet was dissolved in $50 \mathrm{mmol} / \mathrm{L}$ potassium phosphate buffer containing $1 \mathrm{mmol} / \mathrm{L}$ EDTA and $1 \mathrm{mmol} / \mathrm{L}$ DTT ( $\mathrm{pH} \mathrm{7.4)}$ ). Then, $30 \mu \mathrm{L}$ of microsomal protein was separated by
10\% SDS-PAGE and electrotransferred to polyvinylidene difluoride membranes. Membranes were incubated in blocking solution $(50 \mathrm{~g} / \mathrm{L}$ non-fat milk in PBS with $1 \mathrm{~mL} / \mathrm{L}$ Tween 20). These blocking steps were performed at room temperature for $2 \mathrm{~h}$. Membranes were incubated with primary mouse anti-rat CYP2E1 monoclonal antibody (Cat. No.: PM32, Oxford Biomedica Inc., San Diego, CA) or mouse anti-actin monoclonal antibody (Cat. No.: MAB1501, Chemicon International Inc., Temecula, CA) for $2 \mathrm{~h}$. After washing, membranes were incubated with a goat anti-mouse IgG peroxidase-conjugated secondary antibody directed against primary antibody. Membranes were developed by an enhanced chemiluminescence western blot detection system.

\subsection{Preparation of liver homogenate and determination of protein content}

First, $1 \mathrm{~g}$ of liver tissue was added with $4 \mathrm{~mL}$ of $4{ }^{\circ} \mathrm{C}$ buffer $(0.25 \mathrm{mM}$ sucrose, $10 \mathrm{mM}$ Tris- $\mathrm{HCl}$, and $0.25 \mathrm{mM}$ phenylmethylsulfonyl fluoride, $\mathrm{pH}$ 7.4). The Polytron homogenizer (Glas-Col, Terre Haute, IN, USA) was utilized to homogenate the tissue. The homogenate solution was centrifuged at $10,000 \mathrm{~g}$ for $20 \mathrm{~min}$ at $4{ }^{\circ} \mathrm{C}$. The upper layer was collected and stored at $-80^{\circ} \mathrm{C}$ for assay. In order to express the antioxidant enzyme activities per gram of protein, total protein concentration of liver tissues was determined colorimetrically using a Bio-Rad DC protein assay kit (Cat. No.: 500-0116; Bio-Rad Laboratories, Hercules, CA, USA).

\subsection{Determination of biochemical parameters of plasma}

The enzymatic activities of aspartate aminotransferase (AST), alanine aminotransferase (ALT), triacylglycerol (TC), and total cholesterol (TC) in the plasma were measured colorimetrically with an automatic analyzer (Beckman-Coulter Synchron LX20 analyzer; Beckman, Fullerton, CA).

\subsection{Assay of antioxidant enzymes activities in erythrocytes and liver tissues}

\subsubsection{Glutathione peroxidase (GPX) activity}

GPX activity of erythrocytes and liver tissues was determined with a commercial kit (RS 504; Randox Laboratories, Antrim, UK). First, $20 \mu \mathrm{L}$ of the diluted sample were added to $1 \mathrm{~mL}$ of mixed substrate $(4 \mathrm{mmol} / \mathrm{L} \mathrm{GSH}, 0.5 \mathrm{U} / \mathrm{L}$ GRD, and $0.34 \mathrm{mmol} / \mathrm{L}$ NADPH dissolved in $50 \mathrm{mmol} / \mathrm{L}$ phosphate buffer, $\mathrm{pH} 7.2,4.3 \mathrm{mmol} /$ L EDTA). Then, $40 \mu \mathrm{L}$ of cumene hydroperoxide (diluted in deionized water) were added to the mixture. The reaction mixture was incubated at $37^{\circ} \mathrm{C}$, and the absorbance at $340 \mathrm{~nm}$ was determined every $1 \mathrm{~min}$ up to $3 \mathrm{~min}$ using the UV-vis spectrophotometer.

\subsubsection{Glutathione reductase (GRD) activity}

GRD activity of erythrocytes and liver tissues was measured with a commercial kit (Calbiochem 359962; Calbiochem-Novabiochem). First, $200 \mu \mathrm{L}$ of the diluted sample and $400 \mu \mathrm{L}$ of $2.4 \mathrm{mmol} / \mathrm{L}$ GSSG buffer (dissolved in $125 \mathrm{mmol} / \mathrm{L}$ potassium phosphate buffer, pH 7.5, $2.5 \mathrm{mmol} / \mathrm{L}$ EDTA) were added to $400 \mu \mathrm{L}$ of $0.55 \mathrm{mmol} / \mathrm{L}$ $\mathrm{NADPH}$ (dissolved in deionized water). The absorbance was measured at $340 \mathrm{~nm}$ every 1 min up to 5 min using the UV-vis spectrophotometer.

\subsubsection{Superoxide dismutase (SOD) activity}

SOD activity of erythrocytes and liver tissues was measured with a commercial kit (SD 125; Randox Laboratories). First, $50 \mu \mathrm{L}$ of the diluted sample and $1.7 \mathrm{~mL}$ of the mixed substrate $(50 \mu \mathrm{mol} / \mathrm{L}$ xanthine and $25 \mu \mathrm{mol} / \mathrm{L} 2$-(4-iodophenyl)-3-(4nitrophenyl)-5-phenyl tetrazolium chloride, INT) were added to $250 \mu \mathrm{L}$ of xanthin oxidase. The reaction mixture was incubated at $37^{\circ} \mathrm{C}$, and the absorbance was measured at $340 \mathrm{~nm}$ every $1 \mathrm{~min}$ up to $3 \mathrm{~min}$ using the UV-vis spectrophotometer.

\subsubsection{Catalase (CAT) activity}

CAT activity of erythrocytes and liver tissues was determined according to the method reported by Beers and Sizer (1952). First, $100 \mu \mathrm{L}$ of the diluted sample and $1 \mathrm{~mL}$ of $59 \mathrm{mmol} / \mathrm{L} \mathrm{H}_{2} \mathrm{O}_{2}$ (dissolved in $50 \mathrm{mmol} / \mathrm{L}$ potassium phosphate buffer, $\mathrm{pH}$ 7.0) were added to $1.9 \mathrm{~mL}$ of deionized water. The absorbance was measured at $240 \mathrm{~nm}$ every $1 \mathrm{~min}$ up to $3 \mathrm{~min}$ using the UV-vis spectrophotometer.

\subsection{Determination of GSH/GSSG in erythrocytes and liver tissues}

\subsubsection{Total glutathione (GSH) concentration}

The concentration of reduced GSH in erythrocytes and liver tissues was carried out according to the method of Tietze (1969), using GSH $(0-100 \mu \mathrm{M})$ as the standard. The diluted sample solution or standard $(10 \mu \mathrm{L})$ was mixed with $95 \mu \mathrm{L}$ of the reagent $(2 \mathrm{U} / \mathrm{mL}$ glutathione reductase, $200 \mu \mathrm{M} \mathrm{NADPH}$, and $2 \mathrm{mM}$ EDTA in $50 \mathrm{mM}$ phosphate buffer, $\mathrm{pH} 7.2$ ), followed by the addition of $100 \mu \mathrm{L}$ of the reagent ( $10 \mathrm{mM}$ DTNB in $50 \mathrm{mM}$ phosphate buffer, $\mathrm{pH}$ 7.2). The reaction mixture was then incubated at room temperature, and the absorbance at $405 \mathrm{~nm}$ was determined every $1 \mathrm{~min}$ up to 5 min using the ELISA reader (Labsystem Multiskan RC, Finland). The concentration was expressed as GSH ( $\mu \mathrm{M})$ in erythrocytes and liver tissues. 
2.8.2. Oxidized glutathione (GSSG) concentration

The concentration of reduced GSSG in erythrocytes and liver tissues was measured according to the method of Tietze (1969), using GSSG $(0-100 \mu \mathrm{M})$ as the standard. The diluted sample solution or standard $(70 \mu \mathrm{L})$ was mixed with $4 \mu \mathrm{L}$ of 1-methyl-2-vinylpyridinium trifluoromethanesulfonate (M2VP). The mixture was kept for $1 \mathrm{~h}$. The reaction mixture $(10 \mu \mathrm{L})$ was mixed with $95 \mu \mathrm{L}$ of the reagent $(2 \mathrm{U} / \mathrm{mL}$ glutathione reductase, $200 \mu \mathrm{M} \mathrm{NADPH}$, and $2 \mathrm{mM}$ EDTA in $50 \mathrm{mM}$ phosphate buffer, $\mathrm{pH} 7.2$ ), followed by the addition of $100 \mu \mathrm{L}$ of the reagent $(10 \mathrm{mM}$ DTNB in $50 \mathrm{mM}$ phosphate buffer, $\mathrm{pH} 7.2)$. The reaction mixture was then incubated at room temperature, and the absorbance at $405 \mathrm{~nm}$ was determined every $1 \mathrm{~min}$ up to 5 min using the ELISA reader (Labsystem Multiskan RC, Finland). The concentration was expressed as GSSG $(\mu \mathrm{M})$ in erythrocytes and liver tissues.

\subsubsection{Ratio of GSH and GSSG}

The GSH/GSSH is then calculated by dividing the difference between the total GSH and GSSG concentrations (reduced GSH). GSH/GSSG = (total GSH - 2GSSG)/ GSSG.

\subsection{Measurement of lipid peroxidation in plasma and liver tissues}

The quantitative measurement of lipid peroxidation was analyzed by measuring the concentration of thiobarbituric acid reactive substances (TBARS) in plasma and liver tissues using the method of Ohkawa et al. (1979) with minor modifications. $20 \mu \mathrm{L}$ sample (plasma or liver homogenates) or various levels of TMP (1,1,3,3-tetramethoxypropane; as a standard) were shaken with $800 \mu \mathrm{L}$ of $0.22 \% \mathrm{H}_{2} \mathrm{SO}_{4}$ in a $2 \mathrm{~mL}$ centrifuge tube. $100 \mu \mathrm{L}$ of $10 \%$ Phosphotungstic acid and $200 \mu \mathrm{L}$ of $0.67 \%$ TBA (in $\mathrm{H}_{2} \mathrm{O}$ : galacical acetic acid $=1: 1, v / v$ ) were added to the mixture, shaken, and warmed for $60 \mathrm{~min}$ in a boiling water bath followed by rapid cooling. Then it was shaken into a $600 \mu \mathrm{L}$ of $n$-butyl-alcohol layer in a separation tube and MDA conten in the plasma or liver homogenates were determined fluorometrically (excitation and emission wavelengths: $531 \mathrm{~nm}$ vs. $590 \mathrm{~nm}$ ) using a Wallac Victor-2 1420 Multilabel Counter (Perkin-Elmer). The level of lipid peroxides was expressed as nmols MDA per $\mathrm{g}$ tissue (wet $\mathrm{wt}$ )

\subsection{Statistical analysis}

All results are expressed as mean $\pm \operatorname{SEM}(n=6)$. The significance of difference was calculated by Scheffe's test, and results with $p<0.05$ were considered to be statistically significant.

\section{Results}

\subsection{Pathological histology}

Fig. 1 shows that $\mathrm{CCl}_{4}$-induced liver injury causes fatty degeneration of hepatic cells and vacuole formation in the central vein. Table 1 summarizes the data of liver damage induced by $\mathrm{CCl}_{4}$ in pathological histology. The level of vacuole formation and inflammation were significant after chronic $\mathrm{CCl}_{4}$ treatment. Treatments using low dose of silymarin and gallic acid, and high dose of ACBE reduce the injury score of vacuole formation and inflammation. Histological examination showed a preventive effect of ACBE and gallic acid on $\mathrm{CCl}_{4}$-induced hepatoxicity.

\subsection{Effect of A. confusa bark extract on plasma biochemical parameters of liver function}

Serum aminotransferase activities have long been considered effective indicators of hepatic injury. The protective effects of ACBE and gallic acid on $\mathrm{CCl}_{4}$-induced reduction of plasma AST and ALT activities are presented in Table 2. The plasma AST and ALT activities of $\mathrm{CCl}_{4}$ group were dramatically elevated to 210 and $214 \mathrm{U} / \mathrm{L}$ while these values were 68 and $38 \mathrm{U} / \mathrm{L}$, respectively in the control group. However, the groups treated with $50 \mathrm{mg} / \mathrm{kg}$ of silymarin showed significant decrease in elevation of plasma AST and ALT activities significantly $(p<0.05)$, with the values of 116 and $102 \mathrm{U} / \mathrm{L}$, respectively. In addition, there were no significant differences among the groups treated with $50 \mathrm{mg} / \mathrm{kg}$ of silymarin, $50 \mathrm{mg} / \mathrm{kg}$ of ACBE, and $250 \mathrm{mg} / \mathrm{kg}$ of ACBE. Furthermore, treatment with $50 \mathrm{mg} / \mathrm{kg}$ of gallic acid, an active compound of $A$. confusa bark, decreased significantly the elevation of plasma AST and ALT activ- ities compared with those administered with $50 \mathrm{mg} / \mathrm{kg}$ of silymarin $(p<0.05)$.

\subsection{Effect of A. confusa bark extract on antioxidant enzymes activities in erythrocytes}

The activities of SOD, GRD, GPX, and CAT in erythrocytes of $\mathrm{CCl}_{4}$-induced rats are shown in Table 3 . In erythrocytes, $\mathrm{CCl}_{4}$ treatment caused reduction of SOD (19 U/mg), GPX (2.3 U/mg), and CAT (852 U/mg) activities when compared with those in the control group, showing values of $49,3.0$ and $1381 \mathrm{U} / \mathrm{mg}$, respectively $(p<0.05)$. Enhancement of SOD activity was observed in the groups treated with $50 \mathrm{mg} / \mathrm{kg}$ of silymarin $(68 \mathrm{U} / \mathrm{mg}), 50 \mathrm{mg} / \mathrm{kg}$ of ACBE (61 U/mg), $250 \mathrm{mg} / \mathrm{kg}$ of ACBE ( $54 \mathrm{U} / \mathrm{mg}$ ), and $50 \mathrm{mg} / \mathrm{kg}$ of gallic acid $(97 \mathrm{U} / \mathrm{mg})$ compared with those administered with $\mathrm{CCl}_{4}$ alone $(p<0.05)$. However, except for treatment with gallic acid, no significant differences in GRD activity of erythrocytes were observed among the groups. Additionally, the groups treated with $50 \mathrm{mg} / \mathrm{kg}$ of silymarin (3.1 U/mg), $250 \mathrm{mg} / \mathrm{kg}$ of ACBE $(3.0 \mathrm{U} / \mathrm{mg})$, and $50 \mathrm{mg} / \mathrm{kg}$ of gallic acid $(4.9 \mathrm{U} / \mathrm{mg}$ ) were found to have significant increase in GPX activity when compared with the $\mathrm{CCl}_{4}$ group $(p<0.05)$. Enhancement of CAT activity was observed in the group treated with $50 \mathrm{mg} / \mathrm{kg}$ of gallic acid $(1939 \mathrm{U} / \mathrm{mg}$ ) compared with that of the $\mathrm{CCl}_{4}$ group $(p<0.05)$. Furthermore, treatment with $50 \mathrm{mg} / \mathrm{kg}$ of gallic acid increased significantly SOD, GRD, and CAT activities in erythrocytes compared with treatment with $50 \mathrm{mg} /$ $\mathrm{kg}$ silymarin $(p<0.05)$. On the other hand, the silymarin treatment showed enhanced induction of SOD and GPX compared to the $\mathrm{CCl}_{4}$ control. However, there was no statistically difference in CAT although data showed the elevated trend. These results are similar to those reported in the previous study by Rastogi et al. (2001) in alfatoxin B1 induced-hepatotoxic rats. These findings may also be related with the study of Sonnenbichler et al. (1976) who reported that transcription in the livers of rats and mice is accelerated under the influence of silymarin. Furthermore, Machicao and Sonnenbichler (1997) demonstrated that in vitro experiments with isolated cell nuclei and nucleoli the enzymatic activity of DNA-dependent RNA polymerase I is stimulated by silymarin leading to an increase in the rate of protein synthesis.

\subsection{Effect of A. confusa bark extract on antioxidant enzymes activities in liver tissues}

The activities of SOD, GRD, GPX, and CAT in liver tissues of $\mathrm{CCl}_{4}-$ induced rats are shown in Table 4 . Rats in the $\mathrm{CCl}_{4}$ group showed significant reduction in the hepatic GRD $(0.49 \mathrm{U} / \mathrm{g})$ and GPX $(0.21 \mathrm{U} / \mathrm{g})$ activities when compared with the control group, showing values of 0.53 and $0.33 \mathrm{U} / \mathrm{g}(p<0.05)$, respectively. On the other hand, hepatic GRD and GPX activities of the groups treated with $50 \mathrm{mg} / \mathrm{kg}$ of ACBE, $250 \mathrm{mg} / \mathrm{kg}$ of ACBE, and $50 \mathrm{mg} / \mathrm{kg}$ of gallic acid, showing values of $0.58 / 0.28,0.60 / 0.32$ and $0.54 / 0.32 \mathrm{U} / \mathrm{g}$, respectively, were significantly increased compared with those in the $\mathrm{CCl}_{4}$ group $(p<0.05)$. However, the hepatic GPX activity of the silymarin group showed no significant difference when compared with the $\mathrm{CCl}_{4}$ group. No significant differences in hepatic CAT activity were observed between the control group and the $\mathrm{CCl}_{4}$ group. However, the groups treated with $250 \mathrm{mg} / \mathrm{kg}$ of ACBE and $50 \mathrm{mg} /$ $\mathrm{kg}$ of gallic acid showed significant increase in hepatic CAT activity when compared with those administered with $\mathrm{CCl}_{4}$ only $(p<0.05)$.

\subsection{Effect of A. confusa bark extract on GSH/GSSG}

In states of oxidative stress, GSH is converted into GSSG and becomes depleted, leading to lipid peroxidation. Therefore, using GSH/GSSG as a marker for the evaluation of oxidative stress is an effective method (Reckengel et al., 1991). Tables 5 and 6 show 

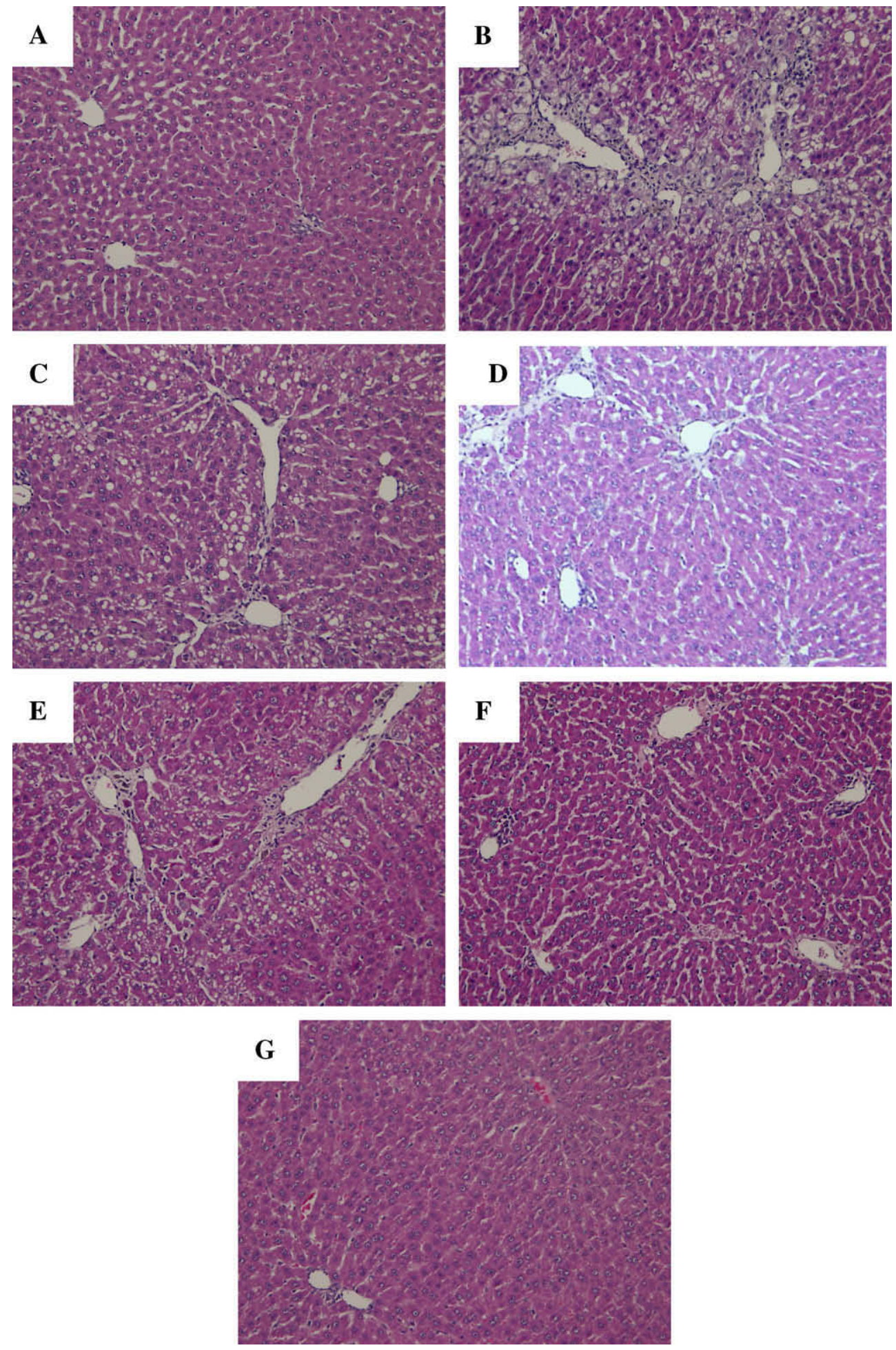

Fig. 1. Effects of A. confusa bark extract and gallic acid on $\mathrm{CCl}_{4}$-induced hepatotoxicity in rats. (A) control group; (B) animals treated with $40 \% \mathrm{CCl}_{4}(0.75 \mathrm{~mL} / \mathrm{kg}$ of bw) showed severe fatty degeneration and vacuole formation; (C) animals treated with silymarin ( $\mathrm{CCl}_{4}$ injection combined the supplementation of silymarin, $50 \mathrm{mg} / \mathrm{kg}$ of bw/day); (D) animals treated with low dose of crude extract ( $\mathrm{CCl}_{4}$ injection combined with supplementation of crude extract at a low dose, $50 \mathrm{mg} / \mathrm{kg}$ of bw/day); (E) animals treated with high dose of crude extract group ( $\mathrm{CCl}_{4}$ injection combined with the supplementation of crude extract at a high dose, $250 \mathrm{mg} / \mathrm{kg}$ of bw/day); (F) animals treated with gallic acid $\left(\mathrm{CCl}_{4}\right.$ injection combined the supplementation of gallic acid, $50 \mathrm{mg} / \mathrm{kg}$ of bw/day) and $(\mathrm{G})$ animals only treated with crude extract (olive oil injection combined with the supplementation of crude extract at a high dose, $250 \mathrm{mg} / \mathrm{kg}$ of bw/day).

the effects of $\mathrm{ACBE}$ on $\mathrm{GSH} / \mathrm{GSSG}$ of $\mathrm{CCl}_{4}$-induced hepatotoxicity in rats. The administration of $250 \mathrm{mg} / \mathrm{kg}$ of $\mathrm{ACBE}$ and $50 \mathrm{mg} / \mathrm{kg}$ of gallic acid to rats resulted in an elevation of GSH/GSSG in erythrocytes, showing values of 82 and 107, respectively. In comparison with the $\mathrm{CCl}_{4}$ group (27), erythrocyte GSH/GSSG was significantly increased in the high-dose group (82) but not in the low-dose group (35). Furthermore, GSH/GSSG in erythrocytes of the group treated with $50 \mathrm{mg} / \mathrm{kg}$ of gallic acid (107) increased significantly when compared with those treated with $50 \mathrm{mg} / \mathrm{kg}$ of silymarin (57) $(p<0.05)$. Interestingly, supplementation of gallic acid could 
Table 1

Effect of A. confusa bark extract and gallic acid on hepatic histopathology scores of liver damage in rat treated with $\mathrm{CCl}_{4}$.

\begin{tabular}{lllll}
\hline Treatments $^{*}$ & \multicolumn{4}{l}{ Injury of scores $^{* *}$} \\
\cline { 2 - 3 } & \multicolumn{2}{l}{ Fatty change (Vacuole formation) } & Inflammation & Necrosis \\
\cline { 2 - 3 } & Small & Big & & \\
\hline Normal control & $0.00 \pm 0.00^{\mathrm{e}}$ & $0.00 \pm 0.00^{\mathrm{b}}$ & & \\
$\mathrm{CCl}_{4}$ control & $1.92 \pm 0.08^{\mathrm{a}}$ & $0.75 \pm 0.11^{\mathrm{a}}$ & $0.58 \pm 0.08^{\mathrm{a}}$ & $0.08 \pm 0.08^{\mathrm{a}}$ \\
$\mathrm{Silymarin}^{\mathrm{a}} \mathrm{CCl}_{4}$ & $0.83 \pm 0.21^{\mathrm{c}, \mathrm{d}}$ & $0.33 \pm 0.17^{\mathrm{b}}$ & $0.50 \pm 0.00^{\mathrm{a}, \mathrm{b}}$ & $0.17 \pm 0.11^{\mathrm{a}}$ \\
$\mathrm{L}-\mathrm{ACBE}+\mathrm{CCl}_{4}$ & $1.42 \pm 0.33^{\mathrm{a}, \mathrm{b}}$ & $0.00 \pm 0.00^{\mathrm{b}}$ & $0.33 \pm 0.11^{\mathrm{b}}$ & $0.08 \pm 0.08^{\mathrm{a}}$ \\
$\mathrm{H}-\mathrm{ACBE}+\mathrm{CCl}_{4}$ & $1.08 \pm 0.24^{\mathrm{b}, \mathrm{c}}$ & $0.00 \pm 0.00^{\mathrm{b}}$ & $0.42 \pm 0.08^{\mathrm{b}}$ & $0.00 \pm 0.00^{\mathrm{a}}$ \\
$\mathrm{H}-\mathrm{ACBE}$ & $0.08 \pm 0.08^{\mathrm{d}, \mathrm{e}}$ & $0.00 \pm 0.00^{\mathrm{b}}$ & $0.25 \pm 0.11^{\mathrm{b}}$ & $0.00 \pm 0.00^{\mathrm{a}}$ \\
$\mathrm{GA}+\mathrm{CCl}_{4}$ & $0.42 \pm 0.24^{\mathrm{e}}$ & $0.00 \pm 0.00^{\mathrm{b}}$ & $0.25 \pm 0.11^{\mathrm{b}}$ & $0.00 \pm 0.00^{\mathrm{a}}$ \\
\hline
\end{tabular}

Seven groups were designed as follows: olive oil (control group), $\mathrm{CCl}_{4}$ injection ( $\mathrm{CCl}_{4}$ group), dietary supplementation with silymarin at a dose of $50 \mathrm{mg} / \mathrm{kg}$ plus $\mathrm{CCl}_{4}$ injection (silymarin group), dietary supplementation with $A$. confusa bark extract at a relatively low dose of $50 \mathrm{mg} / \mathrm{kg}$ plus $\mathrm{CCl}_{4}$ injection (L-ACBE $+\mathrm{CCl}_{4}$ group), dietary supplementation with $A$. confusa bark extract at a relatively high dose of $250 \mathrm{mg} / \mathrm{kg}$ plus $\mathrm{CCl}_{4}$ injection ( $\mathrm{H}-\mathrm{ACBE}+\mathrm{CCl}_{4}$ group), dietary supplementation with A. confusa bark extract at a relatively high dose of $250 \mathrm{mg} / \mathrm{kg}$ (H-ACBE group), dietary supplementation with gallic acid at a dose of $50 \mathrm{mg} / \mathrm{kg}$ plus $\mathrm{CCl}_{4}$ injection ( $\mathrm{GA}+\mathrm{CCl}_{4}$ group). Each value represents the mean $\pm \mathrm{SEM}$ of six rats.

${ }^{*}$ Different letters are significantly different at the level of $p<0.05$ according to the Scheffe's test.

Table 2

Effect of A. confusa bark extract and gallic acid on plasma AST and ALT activities of $\mathrm{CCl}_{4}$-induced hepatotoxicity in rats.

\begin{tabular}{|c|c|c|}
\hline Treatment ${ }^{*}$ & $\operatorname{AST}(\mathrm{U} / \mathrm{L})^{* *}$ & $\operatorname{ALT}(U / L)$ \\
\hline Normal control & $68 \pm 2^{c}$ & $38 \pm 1^{c}$ \\
\hline $\mathrm{CCl}_{4}$ control & $210 \pm 29^{a}$ & $214 \pm 29^{a}$ \\
\hline Silymarin $+\mathrm{CCl}_{4}$ & $116 \pm 12^{\mathrm{b}}$ & $102 \pm 11^{b}$ \\
\hline $\mathrm{L}-\mathrm{ACBE}+\mathrm{CCl}_{4}$ & $84 \pm 8^{\mathrm{b}, \mathrm{c}}$ & $71 \pm 9^{b, c}$ \\
\hline $\mathrm{H}-\mathrm{ACBE}+\mathrm{CCl}_{4}$ & $83 \pm 7^{\mathrm{b}, \mathrm{c}}$ & $65 \pm 11^{\mathrm{b}, \mathrm{c}}$ \\
\hline H-ACBE & $61 \pm 2^{c}$ & $62 \pm 5^{c}$ \\
\hline $\mathrm{GA}+\mathrm{CCl}_{4}$ & $77 \pm 4^{c}$ & $37 \pm 1^{c}$ \\
\hline
\end{tabular}

* Each value represents the mean \pm SEM of six rats.

** Different letters are significantly different at the level of $p<0.05$ according to the Scheffe's test.

Table 3

Effect of A. confusa bark extract and gallic acid on antioxidant enzymes activities in the erythrocytes of $\mathrm{CCl}_{4}$-induced hepatotoxicity in rats.

\begin{tabular}{|c|c|c|c|c|}
\hline Treatment $^{*}$ & $\mathrm{SOD}(\mathrm{U} / \mathrm{mg})^{* *}$ & GRD (U/g) & GPX (U/mg) & CAT (U/mg) \\
\hline Normal control & $49 \pm 6^{b}$ & $2.5 \pm 0.2^{b}$ & $3.0 \pm 0.3^{a}$ & $1381 \pm 199^{\mathrm{b}, \mathrm{c}}$ \\
\hline $\mathrm{CCl}_{4}$ control & $19 \pm 4^{c}$ & $2.1 \pm 0.1^{b}$ & $2.3 \pm 0.2^{b}$ & $852 \pm 16^{d}$ \\
\hline Silymarin $+\mathrm{CCl}_{4}$ & $68 \pm 9^{b}$ & $2.1 \pm 0.2^{b}$ & $3.1 \pm 0.2^{\mathrm{a}}$ & $1337 \pm 172^{b, c, d}$ \\
\hline $\mathrm{L}-\mathrm{ACBE}+\mathrm{CCl}_{4}$ & $61 \pm 4^{\mathrm{b}}$ & $2.6 \pm 0.4^{b}$ & $2.0 \pm 0.2^{b}$ & $1100 \pm 120^{\mathrm{b}, \mathrm{c}, \mathrm{d}}$ \\
\hline $\mathrm{H}-\mathrm{ACBE}+\mathrm{CCl}_{4}$ & $54 \pm 8^{b}$ & $3.1 \pm 0.4^{\mathrm{a}, \mathrm{b}}$ & $3.0 \pm 0.3^{a}$ & $1224 \pm 63^{c, d}$ \\
\hline $\mathrm{H}-\mathrm{ACBE}$ & $46 \pm 6^{b}$ & $2.8 \pm 0.2^{b}$ & $3.2 \pm 0.3^{a}$ & $1674 \pm 298^{\mathrm{a}, \mathrm{b}}$ \\
\hline $\mathrm{GA}+\mathrm{CCl}_{4}$ & $97 \pm 5^{a}$ & $5.1 \pm 0.9^{a}$ & $4.9 \pm 0.9^{a}$ & $1939 \pm 222^{\mathrm{a}}$ \\
\hline
\end{tabular}

* Each value represents the mean \pm SEM of six rats.

* Different letters are significantly different at the level of $p<0.05$ according to the Scheffe's test.

protect GSH/GSSG depletion induced by $\mathrm{CCl}_{4}$ both in both erythrocytes and liver tissues.

\subsection{Effect of A. confusa bark extract on $\mathrm{CCl}_{4}$-induced lipid peroxidation levels}

Tables 5 and 6 show the formation of TBARS in the plasma and liver tissues of rats treated with ACBE. Malondialdehyde (MDA) is the product of lipid peroxidation and is a common marker of lipid peroxidation. The content of TBARS in liver tissues showed no differences among groups (Table 6). However, the content of TBARS
Table 4

Effect of A. confusa bark extract and gallic acid on antioxidant enzymes activities in the liver tissues of $\mathrm{CCl}_{4}$-induced hepatotoxicity in rats.

\begin{tabular}{|c|c|c|c|c|}
\hline Treatment $^{*}$ & $\mathrm{SOD}(\mathrm{U} / \mathrm{g})^{* *}$ & GRD (U/g) & GPX (U/g) & CAT $(U / g)$ \\
\hline trol & $5.3 \pm 0.3^{b}$ & $0.53 \pm 0.00^{\mathrm{b}, \mathrm{c}}$ & $0.33 \pm 0.01^{\mathrm{a}}$ & $55 \pm 11^{\mathrm{a}, \mathrm{b}}$ \\
\hline $\mathrm{CCl}_{4}$ control & $6.9 \pm 0.3^{a}$ & $0.49 \pm 0.02^{d}$ & $0.21 \pm 0.00^{d}$ & $48 \pm 1^{\mathrm{b}}$ \\
\hline Silymarin $+\mathrm{CCl}_{4}$ & $6.5 \pm 0.2^{\mathrm{a}}$ & $0.56 \pm 0.01^{\mathrm{a}, \mathrm{b}}$ & $0.27 \pm 0.00^{\mathrm{c}, \mathrm{d}}$ & $57 \pm 3^{b}$ \\
\hline $\mathrm{L}-\mathrm{ACBE}+\mathrm{CCl}_{4}$ & $6.9 \pm 0.4^{\mathrm{a}}$ & $0.58 \pm 0.01^{\mathrm{a}, \mathrm{b}}$ & $0.28 \pm 0.01^{b, c}$ & $55 \pm 2^{b}$ \\
\hline $\mathrm{H}-\mathrm{ACBE}+\mathrm{CCl}_{4}$ & $6.8 \pm 0.4^{a}$ & $0.60 \pm 0.02^{\mathrm{a}}$ & $0.32 \pm 0.01^{\mathrm{a}, \mathrm{b}}$ & $72 \pm 11^{\mathrm{a}}$ \\
\hline $\mathrm{H}-\mathrm{ACBE}$ & $5.4 \pm 0.1^{b}$ & $0.54 \pm 0.00^{\mathrm{b}, \mathrm{c}}$ & $0.32 \pm 0.01^{\mathrm{a}, \mathrm{b}}$ & $53 \pm 7^{b}$ \\
\hline $\mathrm{GA}+\mathrm{CCl}_{4}$ & $5.6 \pm 0.3^{b}$ & $0.54 \pm 0.02^{b, c}$ & $0.32 \pm 0.01^{\mathrm{a}, \mathrm{b}}$ & $79 \pm 12^{\mathrm{a}}$ \\
\hline
\end{tabular}

* Each value represents the mean \pm SEM of six rats.

*** Different letters are significantly different at the level of $p<0.05$ according to the Scheffe's test.

Table 5

Effect of A. confusa bark extract and gallic acid on TBARS concentration in the plasma and GSH:GSSG ratio in the erythrocytes of $\mathrm{CCl}_{4}$-induced hepatotoxicity in rats.

\begin{tabular}{lll}
\hline Treatment $^{*}$ & TBARS $(\mathrm{MDA}, \mu \mathrm{M})^{* *}$ & GSH/GSSG \\
\hline Normal control & $4.5 \pm 0.2^{\mathrm{b}}$ & $29 \pm 4^{\mathrm{c}}$ \\
$\mathrm{CCl}_{4}$ control & $6.2 \pm 0.1^{\mathrm{a}}$ & $27 \pm 3^{\mathrm{c}}$ \\
Silymarin $+\mathrm{CCl}_{4}$ & $4.1 \pm 0.1^{\mathrm{b}, \mathrm{c}}$ & $57 \pm 9^{\mathrm{b}, \mathrm{c}}$ \\
$\mathrm{L}-\mathrm{ACBE}+\mathrm{CCl}_{4}$ & $3.8 \pm 0.1^{\mathrm{c}}$ & $35 \pm 6^{\mathrm{b}, \mathrm{c}}$ \\
$\mathrm{H}-\mathrm{ACBE}+\mathrm{CCl}_{4}$ & $3.8 \pm 0.1^{\mathrm{c}}$ & $82 \pm 25^{\mathrm{a}, \mathrm{b}}$ \\
$\mathrm{H}-\mathrm{ACBE}$ & $4.2 \pm 0.1^{\mathrm{b}}$ & $85 \pm 20^{\mathrm{a}, \mathrm{b}}$ \\
$\mathrm{GA}+\mathrm{CCl}_{4}$ & $3.3 \pm 0.2^{\mathrm{d}}$ & $107 \pm 31^{\mathrm{a}}$
\end{tabular}

* Each value represents the mean \pm SEM of six rats.

** Different letters are significantly different at the level of $p<0.05$ according to the Scheffe's test.

Table 6

Effect of $A$. confusa bark extract and gallic acid on TBARS concentration and GSH:GSSG ratio in the liver tissues of $\mathrm{CCl}_{4}$-induced hepatotoxicity in rats.

\begin{tabular}{lll}
\hline Treatment $^{*}$ & TBARS (MDA, nmol/g liver) $)^{* *}$ & GSH/GSSG \\
\hline Normal control & $43 \pm 4^{\mathrm{a}, \mathrm{b}}$ & $20 \pm 1^{\mathrm{b}}$ \\
$\mathrm{CCl}_{4}$ control & $57 \pm 5^{\mathrm{a}}$ & $15 \pm 2^{\mathrm{b}}$ \\
Silymarin $^{\mathrm{b}} \mathrm{CCl}_{4}$ & $42 \pm 5^{\mathrm{a}, \mathrm{b}}$ & $41 \pm 14^{\mathrm{a}, \mathrm{b}}$ \\
$\mathrm{L}-\mathrm{ACBE}+\mathrm{CCl}_{4}$ & $48 \pm 7^{\mathrm{a}, \mathrm{b}}$ & $65 \pm 16^{\mathrm{a}, \mathrm{b}}$ \\
$\mathrm{H}-\mathrm{ACBE}+\mathrm{CCl}_{4}$ & $51 \pm 8^{\mathrm{a}, \mathrm{b}}$ & $65 \pm 11^{\mathrm{a}, \mathrm{b}}$ \\
$\mathrm{H}-\mathrm{ACBE}$ & $39 \pm 4^{\mathrm{b}}$ & $61 \pm 1^{\mathrm{a}, \mathrm{b}}$ \\
$\mathrm{GA}+\mathrm{CCl}_{4}$ & $39 \pm 6^{\mathrm{b}}$ & $93 \pm 43^{\mathrm{a}}$
\end{tabular}

* Each value represents the mean \pm SEM of six rats.

* Different letters are significantly different at the level of $p<0.05$ according to the Scheffe's test.

was significantly increased in the plasma of $\mathrm{CCl}_{4}$-treated rats $(6.2 \mu \mathrm{M})$ as compared with that of the control group $(4.5 \mu \mathrm{M})$. Moreover, rats treated with $50 \mathrm{mg} / \mathrm{kg}$ of silymarin $(4.1 \mu \mathrm{M})$, $50 \mathrm{mg} / \mathrm{kg}$ of ACBE $(3.8 \mu \mathrm{M}), 250 \mathrm{mg} / \mathrm{kg}$ of ACBE $(3.8 \mu \mathrm{M})$, and $50 \mathrm{mg} / \mathrm{kg}$ of gallic acid $(3.3 \mu \mathrm{M})$ showed significantly reduced content of TBARS in the plasma $(p<0.05)$ (Table 5$)$. In addition, the concentrations of triacylglycerol and total cholesterol of plasma are shown in Fig. 2. The data show that there is no difference between vehicle control group and $\mathrm{CCl}_{4}$-treated group. Therefore, we considered the changes of plasma lipid levels to be not influenced on the TBARS values by using the methods in our study. Consequently, these results suggest that oxidative stress induced by $\mathrm{CCl}_{4}$ was blocked by the supplementation of ACBE and gallic acid.

\subsection{Effect of A. confusa bark extract on hepatic CYP2E1 expression}

Fig. 3 shows a representative western blot of CYP2E1 levels in liver tissues. Rats in the $\mathrm{CCl}_{4}$ group with the value of $177 \%$, showed significantly increased hepatic CYP2E1 levels relative to those observed in the control group $(100 \%)(p<0.05)$. However, the groups 
(A)

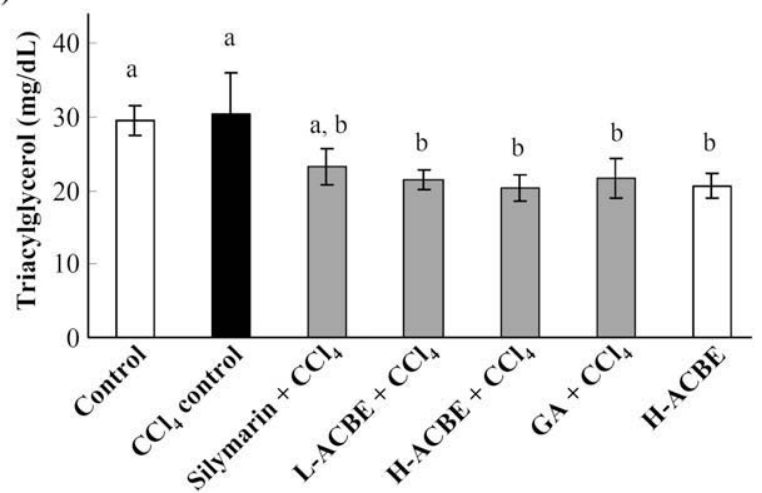

(B)

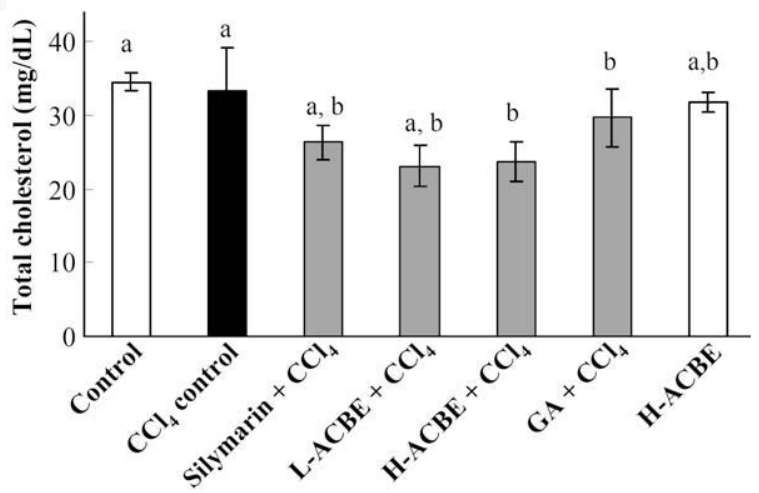

Fig. 2. Effects of $A$. confusa bark extract and gallic acid on triacylglycerol and total cholesterol concentrations of plasma in $\mathrm{CCl}_{4}$-induced hepatotoxicity in rats. Results are mean \pm SEM of six rats. The bars marked by different letters are significantly different at the level of $p<0.05$ according to the Scheffe's test. treated with $50 \mathrm{mg} / \mathrm{kg}$ of silymarin (43\%), $50 \mathrm{mg} / \mathrm{kg}$ of ACBE (16\%), $250 \mathrm{mg} / \mathrm{kg}$ of $\mathrm{ACBE}(26 \%)$, and $50 \mathrm{mg} / \mathrm{kg}$ of gallic acid (45\%) had significantly decreased hepatic CYP2E1 levels relative to those observed in the $\mathrm{CCl}_{4}$ group (177\%) $(p<0.05)$.

\section{Discussion}

Earlier studies have shown that gallic acid, an active component of $A$. confusa bark, possesses potent antioxidant property, including DPPH free radical scavenging activity, ABTS free radical scavenging activity, superoxide free radical scavenging activity, and reducing power (Tung et al., 2007, 2009). The present study showed for the first time that ACBE and gallic acid possess chronic hepatoprotective effect as evidenced by the significant reduction in plasma AST and ALT activities and increase in antioxidant enzymes activities induced by $\mathrm{CCl}_{4}$.

Carbon tetrachloride $\left(\mathrm{CCl}_{4}\right)$, a well-known model compound for producing chemical hepatic injury, requires biotransformation by hepatic microsomal CYP to produce toxic metabolites, namely trichloromethyl free radicals (Brautbar and Williams, 2002). CYP2E1 is the major isozyme involved in bioactivation of $\mathrm{CCl}_{4}$ and subsequent production of free radicals (Sugiyama et al., 2006). $\mathrm{CCl}_{3}$ initiates lipid peroxidation of the membrane of the endoplasmic reticulum and causes a chain reaction. In addition, injury to liver tissues alters their transport function and membrane permeability, leading to leakage of enzymes from the cells. Therefore, the marked release of AST and ALT into the circulation indicates severe damage to hepatic tissue membranes due to $\mathrm{CCl}_{4}$ intoxication (Ahn et al., 2007). In the present study, general indicators of $\mathrm{CCl}_{4}$-induced hepatotoxicity such as histopathological lesions and liverspecific enzyme activities (e.g. AST and ALT) in the plasma were evident. Wills and Asha (2006) reported that silymarin exhibited an excellent hepatoprotection activity at a dose of $50 \mathrm{mg} / \mathrm{kg}$ of

(A)

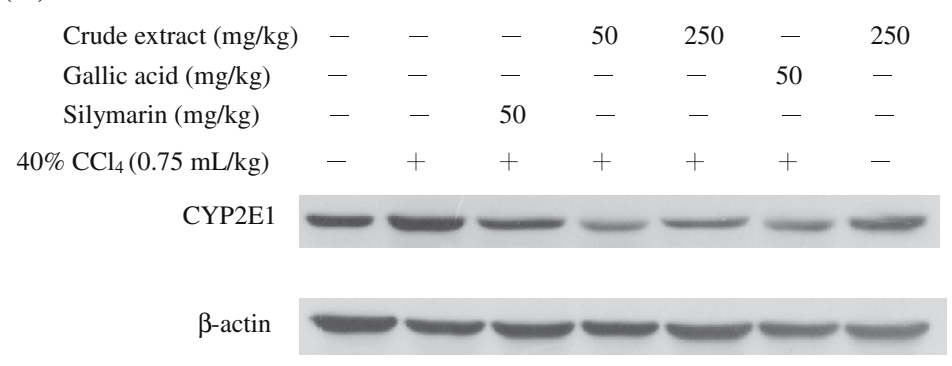

(B)

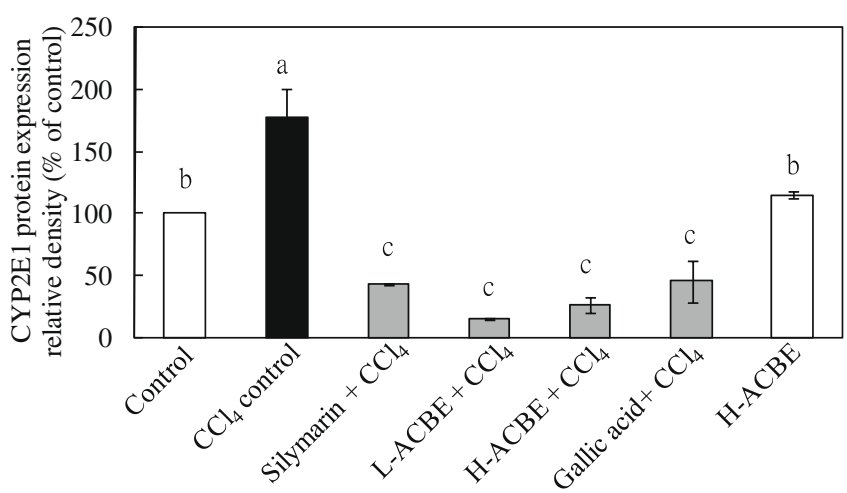

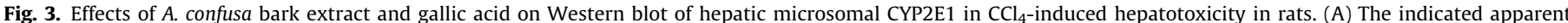

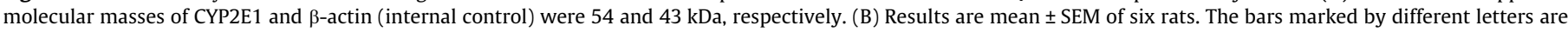
significantly different at the level of $p<0.05$ according to the Scheffe's test. 
bw. In order to compare with silymarin, we select ACBE and gallic acid to test at a dose of $50 \mathrm{mg} / \mathrm{kg}$ of bw in this study. Additionally, the performance of hepatoprotection at a relative high dose of ACBE $(250 \mathrm{mg} / \mathrm{kg}$ of bw) is also concerned. Accordingly, the results revealed that rats fed with $50 \mathrm{mg} / \mathrm{kg}$ of silymarin, $50 \mathrm{mg} / \mathrm{kg}$ of ACBE, $250 \mathrm{mg} / \mathrm{kg}$ of ACBE, and $50 \mathrm{mg} / \mathrm{kg}$ of gallic acid had significantly lowered plasma AST and ALT activities as compared to those administered with $\mathrm{CCl}_{4}$ only $(p<0.05)$. The results are in agreement with those obtained by Jadon et al. (2007) who showed that gallic acid, at $50 \mathrm{mg} / \mathrm{kg}$ body weight, could decrease plasma AST and ALT activities elevated by acute hepatic damage. This evidenced that the administration of crude extract and gallic acid showed hepatoprotective effect under $\mathrm{CCl}_{4}$-induced oxidative stress.

ACBE decreased lipid peroxides in the plasma, increased SOD activity, GPX activity and GSH/GSSG in erythrocytes, and increased GRD, GPX and CAT activities in liver tissues of $\mathrm{CCl}_{4}$-induced rats $(p<0.05)$. Treatment with $250 \mathrm{mg} / \mathrm{kg}$ of ACBE increased significantly hepatic GPX and CAT activities compared with treatment with silymarin $(p<0.05)$. The histological changes induced by $\mathrm{CCl}_{4}$ treatment were evidenced by centrilobular necrosis and bridging hepatic necrosis, and the groups treated with silymarin, ACBE and gallic acid had livers returned to normalcy. ACBE at a dose of $50 \mathrm{mg} / \mathrm{kg}$, which was comparable with silymarin, showed excellent protection on $\mathrm{CCl}_{4}$-induced liver damage. It was also found that ACBE at a dose of $250 \mathrm{mg} / \mathrm{kg}$ increased significantly GPX activities in erythrocytes and CAT activities in liver tissues when compared with ACBE at a dose of $50 \mathrm{mg} / \mathrm{kg}(p<0.05)$. However, except for GPX activities in erythrocytes and CAT activities in liver tissues, there was no significant difference between doses of 50 and $250 \mathrm{mg} / \mathrm{kg}$. Hence, in this present work, a dose-response study between doses of 50 and $250 \mathrm{mg} / \mathrm{kg}$ was unnecessary. On the other hand, in previous works, cinnamates and various derivatives of benzoic acid were identified from the EtOAc fraction of $A$. confusa (Tung et al., 2007, 2009). Phenolic compounds, which are widely distributed in plants, have been considered to play an important antioxidant role as dietary antioxidants for the prevention of oxidative damage in the living system (Hertog et al., 1993). Results revealed that administering ACBE decreased significantly $\mathrm{CCl}_{4}$-induced hepatotoxicity in rats because of antioxidant activities of phenolic compounds.

Our previous study showed that phenolic acids were important antioxidant components in A. confusa, among which gallic acid had the highest antioxidant activities (Tung et al., 2007, 2009). Moreover, the antioxidant enzyme (SOD, GRD, GPX, and CAT) activities were increased by gallic acid in erythrocytes and liver tissues when compared with those administered with $\mathrm{CCl}_{4}$ only $(p<0.05)$. The concentration of TBARS decreased significantly following gallic acid administration in the plasma and liver tissues $(p<0.05)$. These results clearly show that the antioxidant property of gallic acid reduces significantly the damage of $\mathrm{CCl}_{4}$-induced liver injury and activates the biological defense system of the liver. Furthermore, gallic acid appears to scavenge free radicals (Tung et al., 2007), as shown by the inhibition of lipid peroxidation induced by $\mathrm{CCl}_{4}$ in vivo. On the other hand, it has reported that CYP3A activity was reversibly inhibited by gallic acid in human hepatic microsomes in vitro (Stupans et al., 2002). Our results show that gallic acid significantly inhibited $\mathrm{CCl}_{4}$-induced protein expression of CYP2E1 in rat livers, suggesting therapeutic potential for gallic acid in this experimental liver disorder. Further systematic studies on the inhibitory mechanisms of hepatic cytochrome P450 oxidases by gallic acid are warranted.

In conclusion, it is well-known that the hepatoprotective effect has a good correlation with the antioxidant activities (Hung et al., 2006; Jadon et al., 2007). In our previous researches, ACBE and gallic acid have been demonstrated to possess excellent antioxidant activities by various in vitro assays (Chang et al., 2001; Tung et al., 2007, 2009). In this current study, ACBE and gallic acid could reduce $\mathrm{CCl}_{4}$-induced toxicity, particularly hepatotoxicity, by inhibiting lipid peroxidation and CYP2E1 activation, suppressing alanine aminotransferase (ALT) and aspartate aminotransferase (AST) activities, and increasing antioxidant enzyme activity. Therefore, ACBE and gallic acid can be proposed to protect the liver against $\mathrm{CCl}_{4}$-induced oxidative damage in rats, and the hepatoprotective effect might be correlated with its antioxidant and free radical scavenger effects.

\section{Conflict of interest statement}

The authors declare that there are no conflicts of interest.

\section{Acknowledgments}

We thank the National Science Council for the financial support (NSC95-2313-B-002-032) and the experimental forest of National Taiwan University for providing $A$. confusa materials.

\section{References}

Ahn, T.H., Yang, Y.S., Lee, J.C., Moon, C.J., Kim, S.H., Jun, W., Park, S.C., Kim, J.C., 2007. Ameliorative effects of pycnogenol on carbon tetrachloride-induced hepatic oxidative damage in rats. Phytother. Res. 21, 1015-1019.

Beers Jr., R.F., Sizer, I.W., 1952. A spectrophotometric method for measuring the breakdown of hydrogen peroxide by catalase. J. Biol. Chem. 195, 133-140.

Brautbar, N., Williams, J., 2002. 2nd industrial solvents and liver toxicity: risk assessment, risk factors and mechanisms. Int. J. Hyg. Environ. Health 205, 479491.

Chang, C.Y., Chen, Y.L., Yang, S.C., Huang, G.C., Tsi, D., Huang, C.C., Chen, J.R., Li, J.S., 2009. Effect of schisandrin $B$ and sesamin mixture on $\mathrm{CCl}_{4}$-induced hepatic oxidative stress in rats. Phytother. Res. 23, 251-256.

Chang, S.-T., Wu, J.-H., Wang, S.-Y., Kang, P.-L., Yang, N.-S., Shyur, L.-F., 2001. Antioxidant activity of extracts from Acacia confusa bark and heartwood. J. Agric. Food Chem. 49, 3420-3424.

Gowri Shankar, N.L., Manavalan, R., Venkappayya, D., David Raj, C., 2008. Hepatoprotective and antioxidant effects of Commiphora berryi (Arn) Engl bark extract against $\mathrm{CCl}_{4}$-induced oxidative damage in rats. Food Chem. Toxicol. 46, 3182-3185.

Hertog, M.G., Feskens, E.J., Hollman, P.C., Katan, M.B., Kromhout, D., 1993. Dietary antioxidant flavonoids and risk of coronary heart disease: the Zutphen Elderly Study. Lancet 342, 1007-1011

Hsiao, G., Shen, M.Y., Lin, K.H., Lan, M.H., Wu, L.Y., Chou, D.S., Lin, C.H., Su, C.H., Sheu, J.R., 2003. Antioxidative and hepatoprotective effects of Antrodia camphorata extract. J. Agric. Food Chem. 51, 3302-3308.

Huang, C.C., Chen, J.R., Liu, C.C., Chen, K.T., Shieh, M.J., Yang, S.C., 2005. Effects of long-term ethanol consumption on jejunal lipase and disaccharidase activities in male and female rats. World J. Gastroenterol. 11, 2603-2608.

Hung, M.Y., Fu, T.Y., Shih, P.H., Lee, C.P., Yen, G.C., 2006. Du-Zhong (Eucommia ulmoides Oliv.) leaves inhibits $\mathrm{CCl}_{4}$-induced hepatic damage in rats. Food Chem. Toxicol. 44, 1424-1431.

Jadon, A., Bhadauria, M., Shukla, S., 2007. Protective effect of Terminalia belerica Roxb. and gallic acid against carbon tetrachloride induced damage in albino rats. J. Ethnopharmacol. 109, 214-218.

Jain, A., Soni, M., Deb, L., Jain, A., Rout, S.P., Gupta, V.B., Krishna, K.L., 2008. Antioxidant and hepatoprotective activity of ethanolic and aqueous extracts of Momordica dioica Roxb. Leaves. J. Ethnopharmacol. 115, 61-66.

Kan, W.S., 1978. Leguminosae. In: Kan, W.S. (Ed.), Manual of Medicinal Plants in Taiwan, vol. 2. National Research Institute of Chinese Medicine, Taipei, Taiwan, pp. 239-240.

Kuriakose, G.C., Kurup, G.M., 2008. Antioxidant activity of Aulosira fertilisima on $\mathrm{CCl}_{4}$ induced hepatotoxicity in rats. Indian J. Exp. Biol. 46, 52-59.

Liao, J.C., Lin, K.H., Cheng, H.Y., Wu, J.B., Hsieh, M.T., Peng, W.H., 2007. Actinidia rubricaulis attenuates hepatic fibrosis induced by carbon tetrachloride in rats. Am. J. Chin. Med. 35, 81-88.

Lu, H., Liu, G.T., 1992. Anti-oxidant activity of dibenzocyclooctene lignans isolated from schisandraceae. Planta Med. 58, 311-313.

Machicao, F., Sonnenbichler, J., 1997. Mechanism of the stimulation of RNA synthesis in rat liver nuclei by silybin. Hoppe. Seylers. Z. Physiol. Chem. 358, 141-147.

Ohkawa, H., Ohishi, N., Yagi, K., 1979. Assay for lipid peroxides in animal tissues by thiobarbituric acid reaction. Anal. Biochem. 95, 351-358.

Poli, G., Albano, E., Dianzani, M.U., 1987. The role of lipid peroxidation in liver damage. Chem. Phys. Lipids 45, 117-142.

Rastogi, R., Srivastava, A.K., Rastogi, A.K., 2001. Biochemical changes induced in liver and serum of aflatoxin B1-treated male wistar rats: preventive effect of picroliv. Pharmacol. Toxicol. 88, 53-58. 
Reckengel, R.O., Glende Jr., E.A., Britton, R.S., 1991. Free radical damage and lipid peroxidation. In: Meeks, R.G., Harrison, S.D., Bull, R.J. (Eds.), Hepatotoxicology. CRC Press, Florida, pp. 401-436.

Recknagel, R.O., Glende, E.A., Dolak Jr., J.A., Waller, R.L., 1989. Mechanisms of carbon tetrachloride toxicity. Pharmacol. Ther, 43, 139-154.

Shyur, L.F., Huang, C.C., Lo, C.P., Chiu, C.Y., Chen, Y.P., Wang, S.Y., Chang, S.T., 2008. Hepatoprotective phytocompounds from Cryptomeria japonica are potent modulators of inflammatory mediators. Phytochemistry 69, 1348-1358.

Sonnenbichler, J., Mattersberger, J., Rosen, H., 1976. Stimulation of RNA synthesis in rat liver and isolated hepatocytes by silybin, an antihepatotoxic agent from Silybum marianum L. Gaertn. Hoppe. Seylers. Z. Physiol. Chem. 357, 1171 1180.

Stupans, L., Tan, H.W., Kirlich, A., Tuck, K., Hayball, P., Murray, M., 2002. Inhibition of CYP3A-mediated oxidation in human hepatic microsomes by the dietary derived complex phenol, gallic acid. J. Pharm. Pharmacol. 54, 269-275.

Sugiyama, T., Nagata, J., Yamagishi, A., Endoh, K., Saito, M., Yamada, K., Yamada, S. Umegaki, K., 2006. Selective protection of curcumin against carbon tetrachloride-induced inactivation of hepatic cytochrome P450 isozymes in rats. Life Sci. 78, 2188-2193.

Tietze, F., 1969. Enzymic method for quantitative determination of nanogram amounts of total and oxidized glutathione: applications to mammalian blood and other tissues. Anal. Biochem. 27, 502-522.

Tung, Y.T., Wu, J.H., Huang, C.Y., Kuo, Y.H., Chang, S.T., 2009. Antioxidant activities and phytochemical characteristics of extracts from Acacia confusa bark Bioresour. Technol. 100, 509-514.

Tung, Y.T., Wu, J.H., Kuo, Y.H., Chang, S.T., 2007. Antioxidant activities of natural phenolic compounds from Acacia confusa bark. Bioresour. Technol. 98, 11201123.

Wills, P.J., Asha, V.V., 2006. Protective effect of Lygodium flexuosum (L.) Sw. extract against carbon tetrachloride-induced acute liver injury in rats. J. Ethnopharmacol. 107, 7-11.

Wu, J.H., Tung, Y.T., Wang, S.Y., Shyur, L.F., Kuo, Y.H., Chang, S.T., 2005. Phenolic antioxidants from the heartwood of Acacia confusa. J. Agric. Food Chem. 53, 5917-5921. 